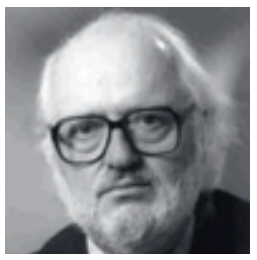

\title{
Kunst på blåresept
}

\section{De aller fleste leger jeg har møtt har ved siden av sin medisinske gjerning hatt en interesse som er blitt noe mer enn hobby. Jeg kjenner leger som er meget habile musikere og spiller i symfoniorkestre. De fleste av mine legevenner er svært glade i musikk og vet mye om det.}

Jeg har også møtt leger som kombinerer medisin med et skjønnlitterært forfatterskap, for eksempel den egyptiske Nawal ElSaadawi. Jeg anbefaler alltid hennes bøker, og hennes uredde synspunkter kan man også stifte bekjentskap med i Ny Tids spalter.

Jeg husker spesielt en kommentar der hun tok et kraftig oppgjør med det muslimske jomfruelighetsideal som slett ikke er så annerledes enn det som hersket i kristelige kretser i vårt land da jeg var barn.

Er det et tegn på høy moral at jomfruhinnen er intakt, spurte Nawal El-Saadawi, og hun viser til «kinesiske jomfruhinner». Hun spør seg selv: Finnes det en forbindelse mellom bruk av heldekkende klær og seksuell og moralsk løssluppenhet? Hvordan kan det ha seg at markedsføringen av den industrielle jomfruhinne fra Kina kunne bli så stor. Hvordan kan synet av et utildekket kvinneansikt få menn til å forlate sine koner og heller følge etter disse kunstige jomfruer?

Nawal El-Saadawi forteller at hun på flyet fra Skopje i Makedonia der hun hadde deltatt på en konferanse, satt ved siden av en tyrkisk mann som mente det var moralsk å foretrekke, men ikke religiøst påbudt å bruke niqab. Ifølge mannen beskytter slike plagg kvinner fra mannens blikk på gaten. El-Saadawi konkluderer med dette retoriske spørsmål: Så da dekker vi øynene til disse mennene i stedet for å dekke til kvinners ansikt?

Det er bare synd at en del norske venstreradikale og feminister ikke lærer av en lege og forfatter som Nawal El-Sadawi. De demonstrerer en fullstendig mangel på solidaritet med de flotte og modige islamske kvinner som med livet som innsats trosser mannsbastionene i enkelte muslimske land og også herser i gettoene i Vest-Europa, til og med i Norge. Det moralpoliti som finnes i muslimske miljøer i dag, minner meg om moralens strenge voktere i min dissenterbarndom da jeg måtte sove med hendene over dynen for ikke å bli fristet til å onanere og jentene skulle tildekke armer og ben. Hvorfor skal det være bedre med muslimsk moralpoliti i dag enn det var med lav- og frikirkelige moralvoktere før i tiden?

Dere dreper oss med deres toleranse, ropte en muslimsk feminist i fortvilelse, en toleranse som ikke kommer de kjempende kvinner til gode, men bygger opp om de mannsdominerte holdninger.

Jeg er glad for at så mange unge norske muslimer nå velger legeyrket. Kanskje vil noen av dem også bli forfattere. Vi trenger denne type innsikt i miljøer som ellers vil kunne virke fremmede og skremmende på oss. Da ville nordmenn kanskje skjønne at det eksisterer et islamsk mangfold. Islam er like variert og motsetningsfylt som den kristne verden. Kanskje er det skjønnlitteratur mer enn rene fagbøker som åpner for en slik erkjennelse, og det er åpenbart en fordel at forfatteren også er lege.

Jeg hadde en gang en sjef som hadde piano på sitt kontor slik at han kunne spille når han ikke strikket eller leste romaner og dikt. Det var kringkastingssjef Hans Jakob Ustvedt. Han var et kulturmenneske, og det preget hans virke som kringkastingssjef.

For meg ble han en redningsmann da byråkratene på Marienlyst reagerte skarpt på at jeg hadde brukt litt penger på bøker under et lengre opphold i Midtøsten. Ustvedt innkalte den nitide funksjonæren og skjelte ham ut etter - ja, nettopp noter. «Endelig en medarbeider som leser bøker,» ropte Ustvedt og kastet byråkraten på dør.

Jeg møtte en gammel venn som hadde ligget på et sykehus der Hans Jakob Ustvedt var overlege. Han fortalte at Ustvedt alltid hadde et par bøker med seg når han gikk visitt, og dem lånte han gjerne ut til pasientene. Ustvedt forstod at litteratur og musikk var den beste terapi, og han sa i fullt alvor at prosa og poesi burde være på blåresept.

$$
\text { Gam Qkto gatansen }
$$

\section{I neste nummer:}

Warfarin og naturmidler

Brannskader

Blodtrykksapparater
Sykling

Ryggmargsskade

Unyttige metoder 